https://dx.doi.org/10.4314/ijs.v19i1.3

Ife Journal of Science vol. 19, no. 1 (2017)

\title{
MORPHOLOGICAL VARIABILITY OF TILAPIA ZILLII (GERVAIS, 1848) FROM SELECTED RESERVOIRS IN SOUTHWESTERN, NIGERIA
}

\author{
*Oladimeji T. E. and OlaosebikanT. O. \\ Department of Zoology, Obafemi Awolowo University, Ile-Ife, Nigeria \\ *Corresponding author \\ E-mail: tofunmioladimeji9@gmail.com, tollyvic@yahoo.com \\ (Received: 30th September, 2016; Accepted: 26th May, 2017)
}

ABSTRACT

\begin{abstract}
Tilapia zillii is one of the dominant cichlids in southwestern reservoirs of Nigeria. Morphological variation was investigated among three populations (Opa, Ero and Asejire reservoirs) of this species using univariate and multivariate analysis. This was with a view to determining the pattern of morphological differentiation among them. Measurements of twenty five morphometric characters and six meristic counts were recorded on fifty specimens each. Univariate analysis of variance showed significant differences $(p<0.005)$ between the means of the three groups for 20 out of 25 morphometric measurements while there was no significant difference between the means of the three groups for most of the meristic characters. Canonical variate analysis results for the morphometric data shows overlap of clusters of fish specimens from Opa and Ero Reservoirs as well as Ero and Asejire Reservoirs. However, there was no overlap between T. zillii samples from Asejire and Ero Reservoir. Results established heterogeneity in morphology among populations of Tilapia zillii inhabiting the three reservoirs based on univariate and multivariate analysis of the morphometric characters only. The meristic characters could not delineate the three populations. The study therefore concluded that populations of T. qillii from Ero and Asejire reservoirs were phenotypically separable populations of the same species while those from Opa reservoir are somewhat morphologically related to both of them.
\end{abstract}

Keywords: Meristics, Morphometrics, Phenotypically, Reservoir, Variation

\section{INTRODUCTION}

Tilapia zillii, an African native fish species is one of the predominant fishes with the highest number of catches in Opa, Ero and Asejire reservoirs of Southwestern Nigeria (Agbabiaka, 2010; Ipinmoroti, 2013). It is a cheap source of highly nutritive protein and is widely acceptable due to its good taste and high fillet quality. It is also an important food fish that can be cultured in either fresh or salt water in tropical and subtropical climates (Lim and Webster, 2006).

Morphology, which is the study of form and structure of organisms, is very important in biology. It is of high relevance in population studies as it is useful in distinguishing species taxonomically and establishing evolutionary relationships (Deesri et al., 2009). Morphological description (morphometrics and meristics) are vigorous tools for measuring discreteness of the same species (Cadrin, 2000). Morphometrics is the quantitative analysis of form; both size and shape while meristic means serial body counts.

Morphometrics and meristic studies of fish populations have been used to identify stocks of fish and to separate different morphotypes (Doherty and McCarthy 2004; Jayasankar et al., 2004). Studies on morphological variations in fish populations are also useful in phylogenetics and in providing information for subsequent studies on the genetic improvement of stocks. Morphological variation between populations can provide a basis for population structure, and may be applicable for studying short-term, environmentally induced variation geared towards successful fisheries management (Murta, 2000; Pinheiro et al., 2005).

One of the major forces in the evolution of new species is the formation of different morphologies within the same species that specializes in different use of resources (Robinson, 1994). Fish is highly susceptible to environmentally induced morphological variations than do any other vertebrates such that they demonstrate greater variations within and between populations (Allendorf et al., 1987; Wimberger, 1992). Morphometric characters can show high plasticity in response to differences in environmental conditions such as food (benthic-pelagic feeding niche continuum), presence of predators, water 
velocity, salinity and temperature (Kristjánsson, 2002). Also selection pressures operating within different habitats or habitat units favor specific traits more than the others as traits that are well suited to the conditions found in one habitat may be ill-suited to those found in others (Webster et al., 2011). Several authors have reported intraspecific morphological variations within populations of numerous species of fishes occurring across environmental gradients such as flow regime, water depth, water chemistry, substrate type, predation risk and prey assemblage (Bentzen and McPhail, 1984; Cresko and Baker, 1996; Eklov and Jonsson, 2007; Schluter, 1995; Svanback and Eklov, 2006). In Nigeria, reports on morphological diversity of fishes within populations of the same specie includes those by Omoniyi and Agbon, 2008; Solomon et al., 2015; Oladimeji et al., 2015; Ukenye et al 2015 amongst others.

There is paucity of information on the morphological diversities of Tilapia zillii in Nigerian inland waters. This study therefore aims to determine the morphological variations of Tilapia zillii from three selected reservoirs in Southwest, Nigeria.

\section{METHODOLOGY \\ Description of Study Area}

The three selected reservoirs used in this study are: Opa Reservoir, Ero Reservoir and Asejire Reservoir.

\section{Opa Reservoir}

The Opa Reservoir is located in Ile-Ife, Ife Central Local Government Area of Osun State Nigeria. It was established in 1978 by the impoundment of Opa River which took its source from Oke-Opa hills for the primary purpose of supplying potable drinking water to Obafemi Awolowo University community. It lies between longitudes $004^{\circ} 030^{\prime}$ to $004^{\circ} 040^{\prime}$ East of the Greenwich and latitudes $07^{\circ}$ $27^{\prime}$ to $07^{\circ} 35^{\prime}$ North of the Equator (Figure 1). The major tributaries are rivers Obubu and Esinmirin. The reservoir has a crest of about $300 \mathrm{~m}$ long and a height of $15 \mathrm{~m}$ from its foundation. The catchment area is about $116 \mathrm{~km}^{2}$; surface area of $0.95 \mathrm{~km}^{2}$ and a maximum capacity of about 675 $\mathrm{m}^{3}$. The minimum depth is $0.95 \mathrm{~m}$ while the maximum depth is $6.4 \mathrm{~m}$. The mean annual temperature of the area is $27{ }^{\circ} \mathrm{C}$ (Akinbuwa and Adeniyi, 1996).

\section{Ero Reservoir}

Ero reservoir is located at Ikun Ekiti in Moba Local Government Area of Ekiti State. The dam is constructed on Ero River which takes its source from the highland region of Orin-Ekiti, in IdoOsi Local Government (Adedeji, 1993). Geographically, Ero Reservoir is located on the intersect of latitude $07^{\circ} 59^{\prime} \mathrm{N}$ and longitude $005^{\circ}$ $012^{\prime} \mathrm{E}$ (Figure 2). The impoundment area is about $4.5 \mathrm{~km}^{2}$, the water surface area is about 450 hectares and it has a maximum capacity of about 20.9 million cubic metres.

\section{Asejire Reservoir}

Asejire Reservoir is in Oyo State in Southwestern Nigeria, created by the impoundment of River Osun. The reservoir was built in the late 1960s. It is found in between latitude $07^{\circ} 21^{\prime} 45^{\prime \prime} \mathrm{N}-7^{\circ}$ $36^{\prime} 25^{\prime \prime} \mathrm{N}$ and longitude $004^{\circ} 08^{\prime} 00^{\prime \prime} \mathrm{E}$ $004^{\circ} 13^{\prime} 33^{\prime \prime} \mathrm{E}$. (Figure 3). The Reservoir provides water to the Asejire and Osegere water treatment plants in Ibadan. It has a capacity of about 80 million litres per day, of which $80 \%$ is used for domestic purposes. The catchment area is 7,800 $\mathrm{km}^{2}$ and the impounded area is $23.42 \mathrm{~km}^{2}(2,342$ hectares). The reservoir has a normal pool elevation (water level) of $150 \mathrm{~m}$ and maximum flood elevation of $152.4 \mathrm{~m}$. The surface area is about $24 \mathrm{~km}^{2}$ (Ayodele, 1979). 


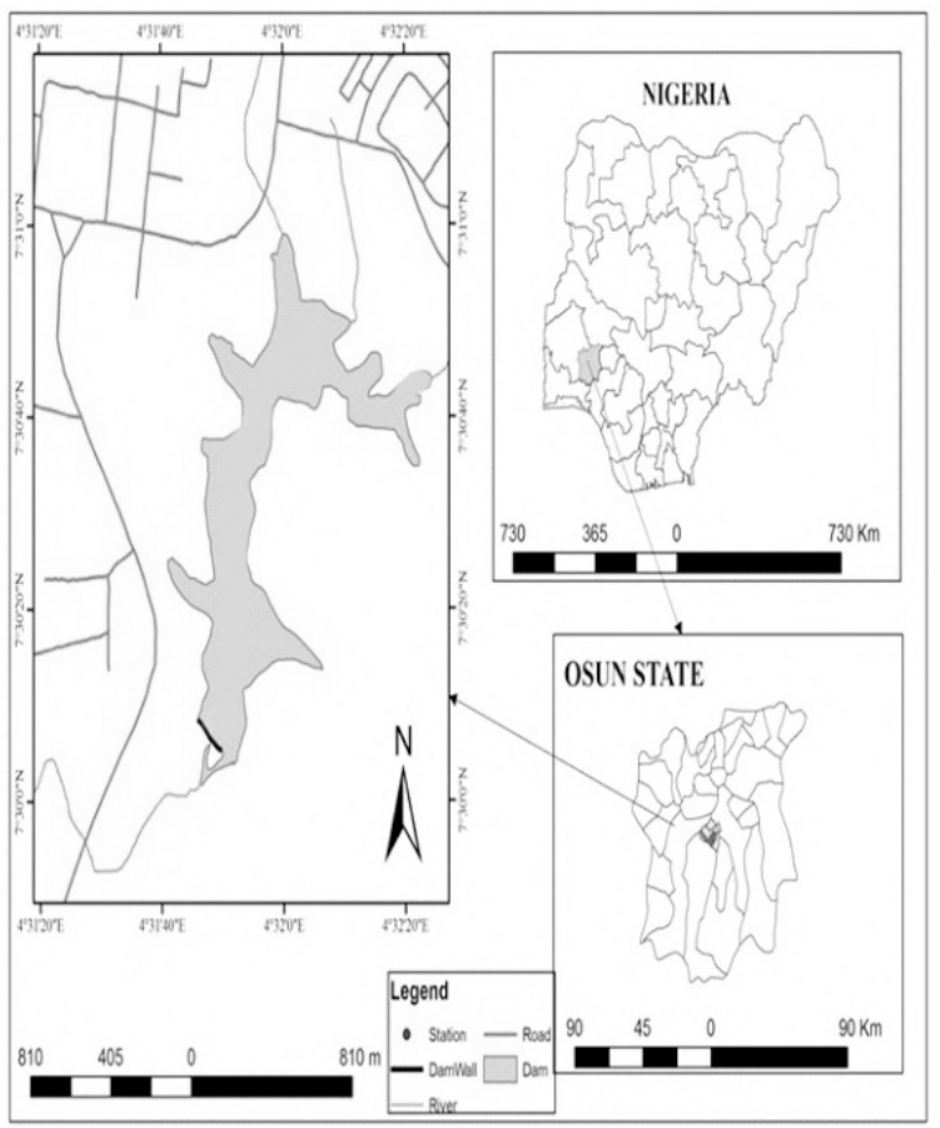

Figure 1: Map of Opa Reservoir in Ile-Ife, Osun State, Nigeria
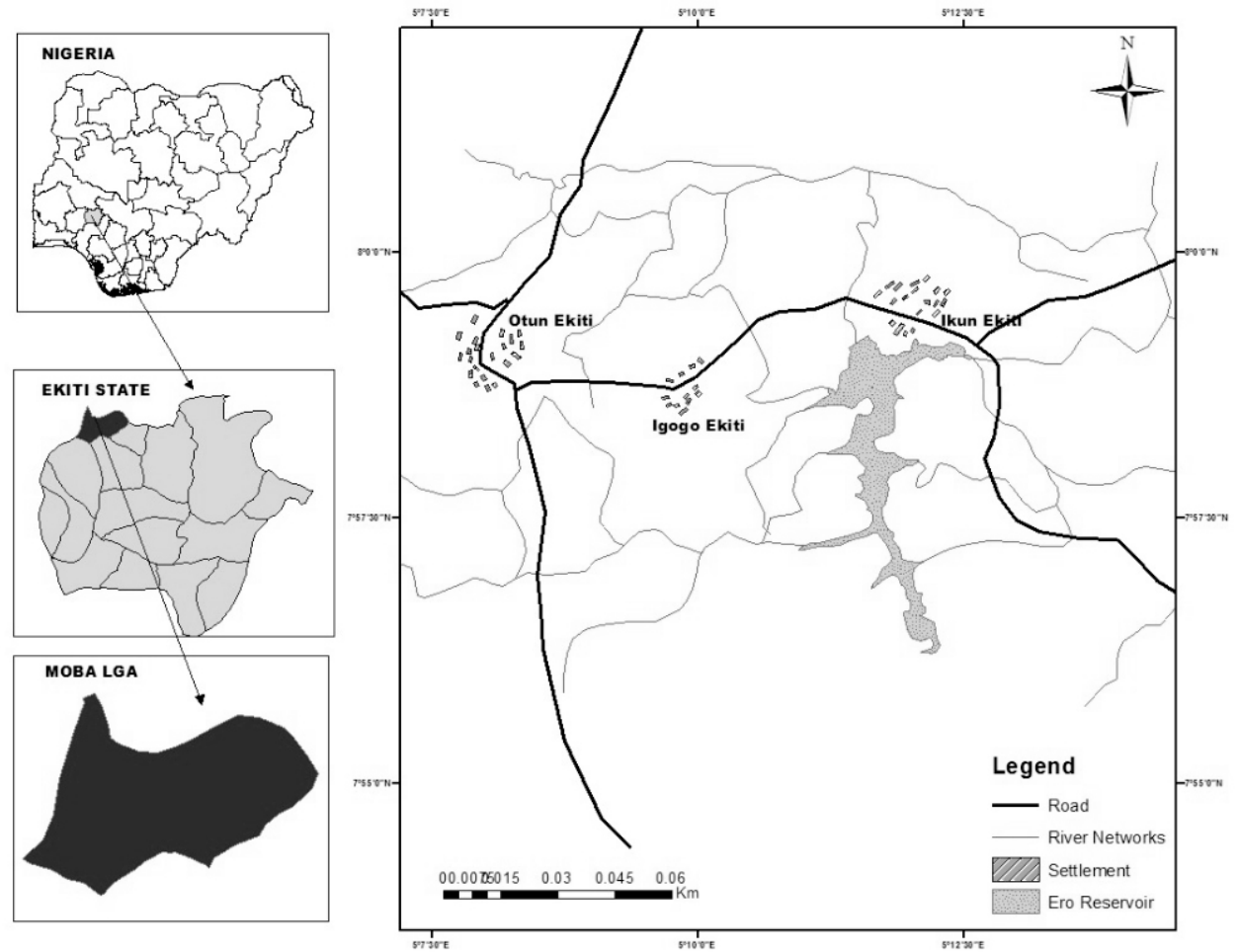

Figure 2: Map of Ero Reservoir in Ikun Ekiti, Ekiti State, Nigeria. 


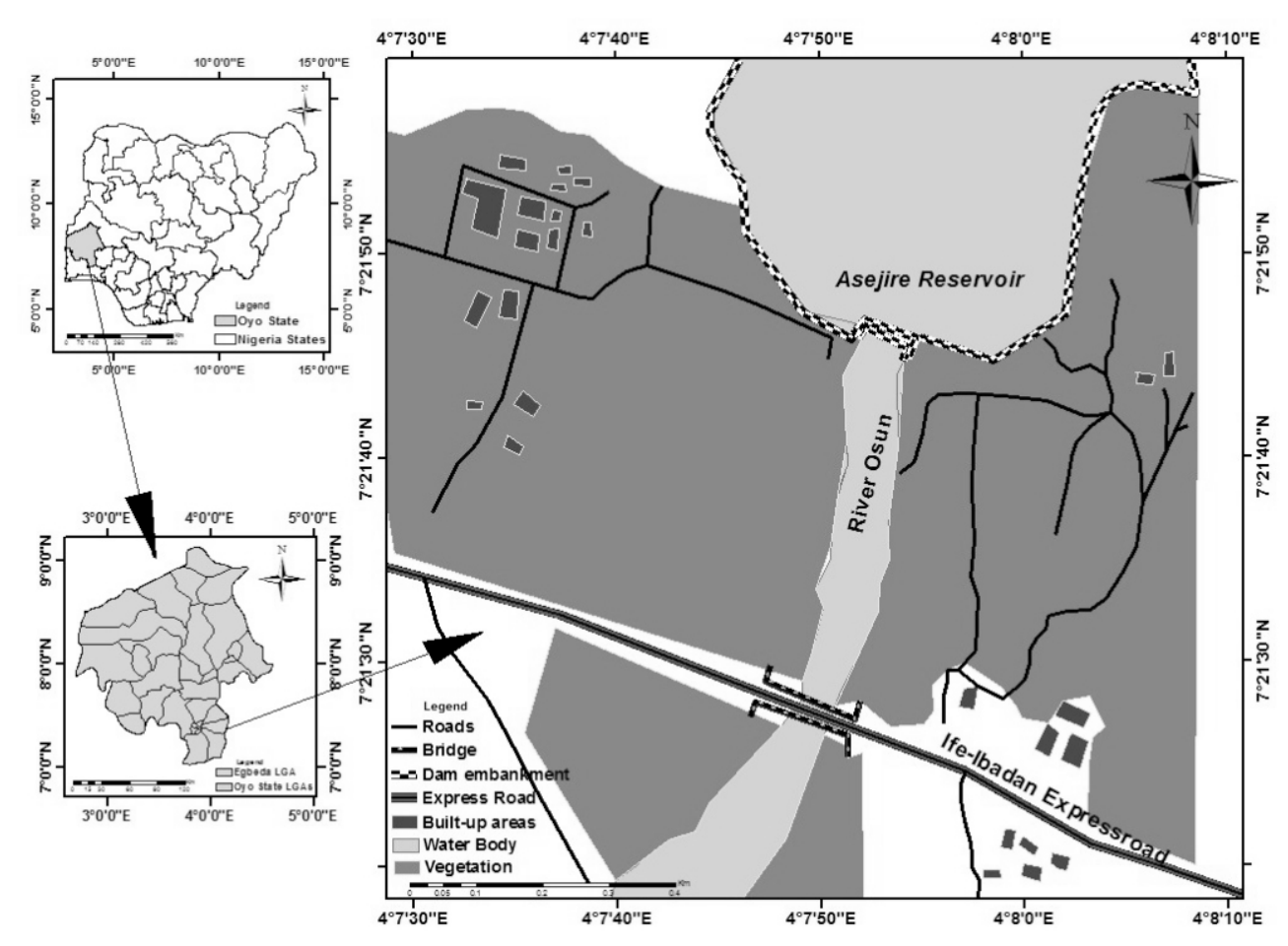

Figure 3: Map of Asejire Reservoir in Asejire, Oyo State, Nigeria.

\section{Fish Sampling}

A total of 150 samples of Tilapia zillii were collected between July and September 2015, from Opa Reservoir, Ero Reservoir and Asejire Reservoir (50 samples each). The Fish samples were collected on a monthly basis from landings of commercial fishermen. All collected specimens were packed in a big container containing ice cubes and were transported to the laboratory for further analysis. The samples were identified using the identification keys prepared by Paugy et al. (2003) and Adesulu and Sydenham (2007).

\section{Morphometric studies}

Twenty five (25) morphometric characters according to Dunz and Schliewen (2010) were measured to the nearest millimeter with digital calipers (NEIKO $01407 \mathrm{~A}$ ) in all the sampled fish specimens. These include: Total Length (TL), Standard Length (SL), Head Length (HL), Body Depth (BD), Snout Length (SNL), Cheek Depth (CHD), Eye Length (EYL), Dorsal Fin Length (DFL), Anal Fin Length (AFL), Length of Last Dorsal Spine (LDS), Length of Third Anal Spine (LTAS), Pelvic Fin Length (PFL), Pre Dorsal Distance (PDD), Upper Lip Length (ULL), Lower Jaw Length (LJL), Lower Lip Width (LLW), Lower Lip Length (LLL), Pectoral Fin Length (PECFL),
Pre Orbital Distance (POD), Caudal Peduncle Length (CPL), Caudal Peduncle Depth (CPD), Lower Jaw Width (LJW), Pelvic Spine Length (PSL), Pre Anal Distance (PAD) and Distance of Lower Jaw to Pelvic Fin (PELD).

Six meristic characters were counted and recorded which include: Number of scales on lateral line, dorsal spines, dorsal rays, gill rakers, anal fin rays and anal fin spines.

\section{Statistical Analysis}

One-way analysis of variance (ANOVA) was performed on the morphometric and meristic characters to test the variation for each trait among the three fish populations using SPSS 21.

Multivariate analyses were carried out separately on morphometric and meristic data. This is because morphometric characters are continuous while the meristic characters are discrete. Furthermore, the meristic characters are fixed early in development while the morphometric characters are more susceptible to environmental variables (Allendorf et al., 1987).

Measurements of each morphometric character were standardized to fish size (SL) in accordance 
with Reist (1985). This was done to remove sizeeffect using percentage standard length as follows: $M n=(M o / S L) \%$, where:

$M o$ is the original measurement; and

$S L$ is the standard length.

Size-corrected data were analyzed by multivariate method using Canonical Variates Analysis (CVA) and Principal Component Analysis (PCA), on PAST software (Hammer et al., 2001). To find out the morphometric factors that can discriminate among the three populations, Principal Component Analysis (PCA) was used in which factor loadings based on Eigen values were used to determine the morphometric factors.

\section{RESULTS}

One-way analysis of variance (ANOVA) revealed that there were significant differences $(\mathrm{P} \leqslant 0.005)$, between the three studied populations (Opa, Ero and Asejire) and within each population for 20 out of the 25 morphometric characters, revealing great heterogeneity in the populations The characters include total length, standard length, head length, body depth snout length, cheek depth, dorsal fin length, anal fin length, length of last dorsal spine, pelvic fin length, pre dorsal distance, upper lip length, lower lip width, lower lip length, pectoral fin length, caudal peduncle length, caudal peduncle depth, pelvic spine length, pre anal distance and distance of lower jaw to pelvic fin. However there were no significant differences $(\mathrm{P}>0.005)$ between and within populations for most of the meristic characters studied. The Canonical Variates Analysis (CVA) diagram of the morphometric measurements of T. zillii from the three Reservoirs of study showed that there is an overlap of data between populations from Opa Reservoir (red), and Asejire Reservoir (Green); and a slight overlap between populations from Opa Reservoir (red) and Ero Reservoir (blue) (Figure 4). There is a clear separation between populations from Ero Reservoir (blue) and Asejire reservoir (Green) (Figure 4). The morphometric character loadings on PC1 of the principal components analysis, showed pectoral fin length (loading 0.719), as the character most responsible for variation among the studied populations of T. zillii (Figure 5).

Canonical Variates Analysis (CVA) diagram of the six meristic counts of T. qillii from the three reservoirs of study revealed a high level of relatedness among the meristic characters studied in the three fish populations as there was a large overlap of clusters (Figure 6). However, loadings on PC 1 of the PCA identified "the number of scales on the lateral lines" (loading, 0.9704) as the meristic character that varied most among the three T. zillii populations (Figure 7). The eigen values and corresponding percentage variance from principal component analysis (PCA) of the morphometric and meristic characters respectively across the three studied populations are shown in tables 1 and 2 respectively. These components are showing the distribution of variation among the components in the PCA. For the morphometric characters, PC I accounted for $36 \%$ of the variation, PC II for $12.5 \%$ and PC III for $11.01 \%$ (Table 1). For the meristic characters, PC I accounted for $50.3 \%$ of the variation, PC II for $27.4 \%$ and PC III for $10.8 \%$ (Table 2). 


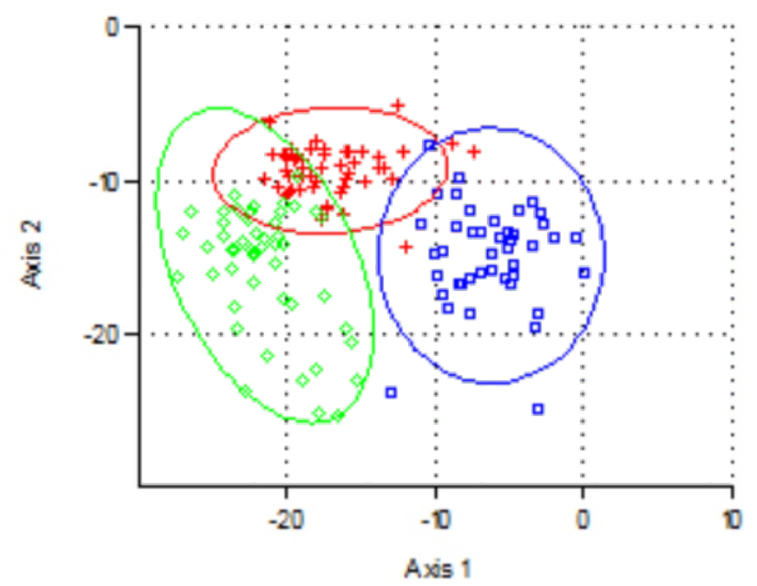

Figure 4: Canonical Variates Analysis (CVA) based on 24 morphometric measurements of T. zillii showing overlap of characters among the three populations from Opa Reservoir (red), Asejire Reservoir (green) and Ero Reservoir (blue).

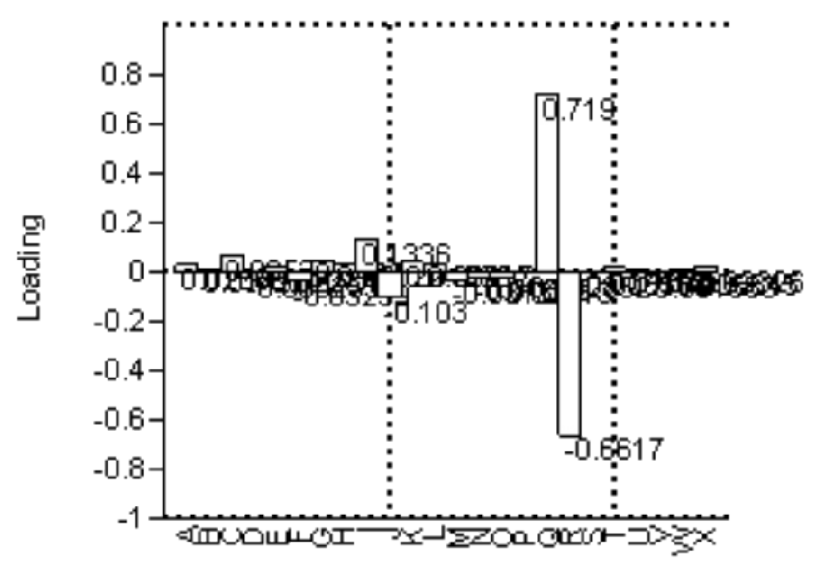

Figure 5: Respective T. zillii morphometric characters and their loadings on PC1 of the Principal Components Analysis showing pectoral fin length as the character most responsible for variation among the studied populations of T. zillii.

$\mathrm{A}=$ total length $\mathrm{B}=$ head length $\mathrm{C}=$ body depth, $\mathrm{D}=$ snout length, $\mathrm{E}=$ cheek depth, $\mathrm{F}=$ eye length, $\mathrm{G}=$ dorsal fin length, $\mathrm{H}=$ anal fin length, $\mathrm{I}=$ length of last dorsal spine, $\mathrm{J}=$ length of third anal spine, $\mathrm{K}=$ pelvic fin length, $\mathrm{L}=$ pre dorsal distance, $\mathrm{M}=$ upper lip length, $\mathrm{N}=$ lower jawlength, $\mathrm{O}=$ lower lip width, $\mathrm{P}=$ lower lip length, $\mathrm{Q}=$ pectoral fin length, $\mathrm{R}=$ preorbital distance, $\mathrm{S}=$ caudal peduncle length, $\mathrm{T}=$ caudal peduncledepth, $\mathrm{U}=$ lower jaw width, $\mathrm{V}=$ pelvic spine length, $\mathrm{W}=$ pre anal distance and $\mathrm{X}=$ distance lower jaw to pelvic fin.

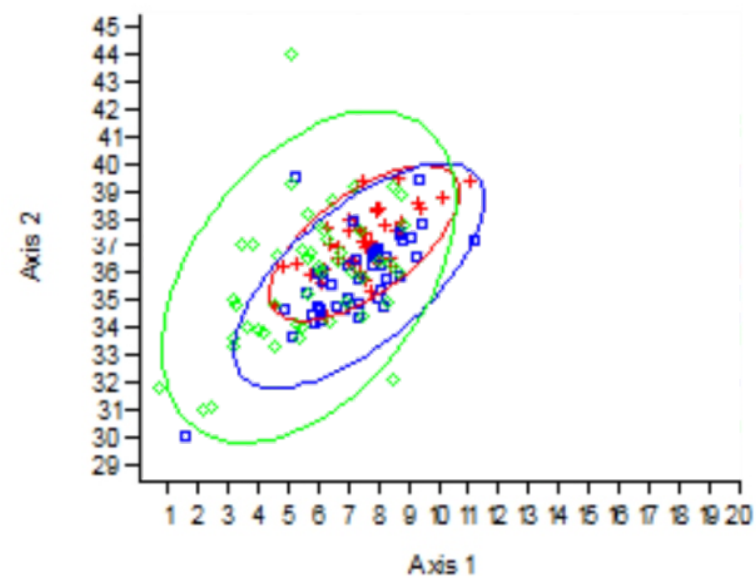

Figure 6: Canonical Variates Analysis (CVA) based on 6 meristic counts of T. zillii from Opa Reservoir (red), Asejire Reservoir (green) and Ero Reservoir (blue) showing homogeneity of characters. 


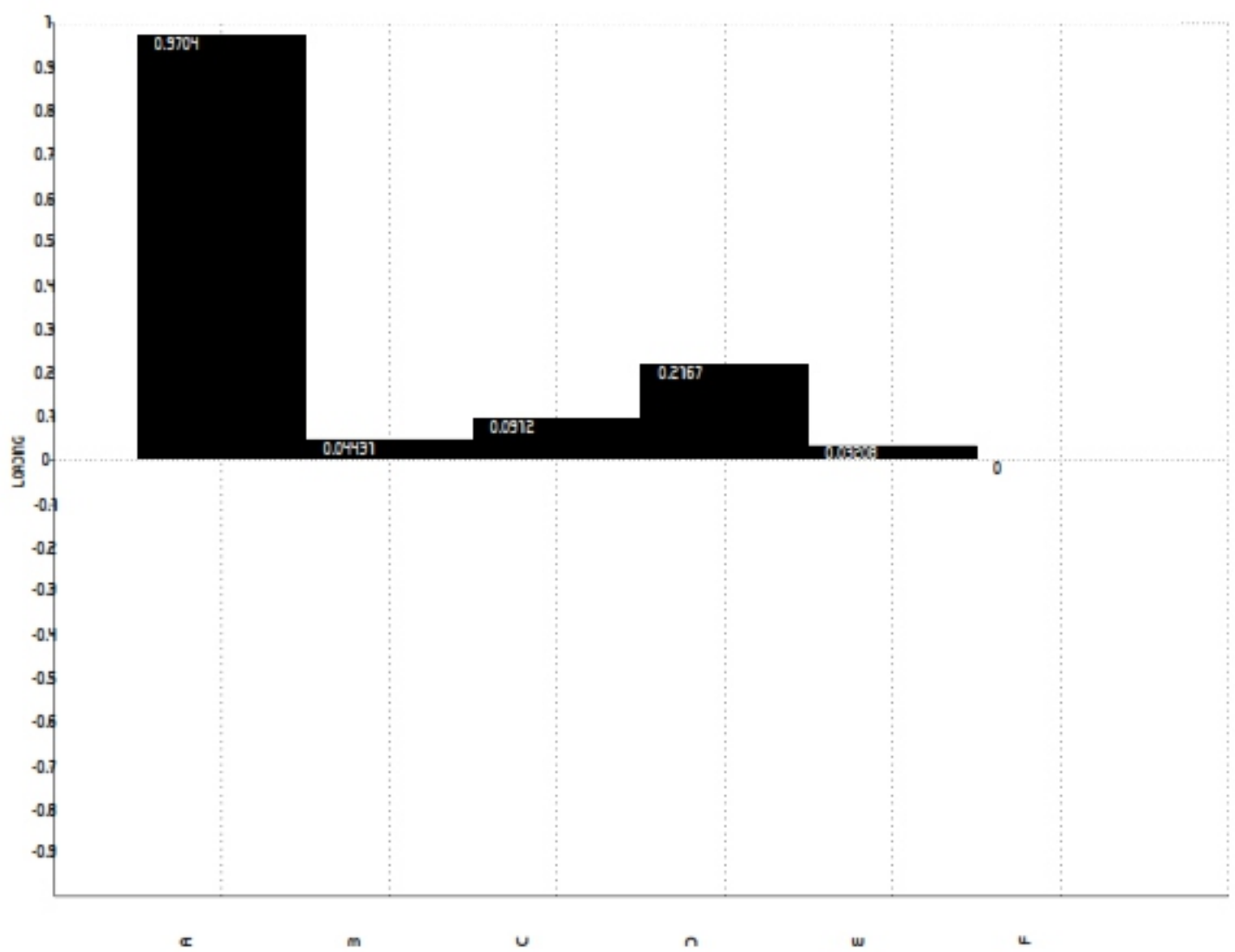

Figure 7: Respective T. zillii meristic counts and their loadings on PC1 of the principal components analysis showing "number of scales on lateral line" as the meristic character most responsible for variation among the three studied populations of $T$. zillii. $\mathrm{A}=$ number of scales on lateral lines, $\mathrm{B}=$ dorsal spine, $\mathrm{C}=$ dorsal ray, $\mathrm{D}=$ gill rakers, $\mathrm{E}=$ anal fin ray and $\mathrm{F}=$ anal fin spine.

Table 1: Distribution of variation of morphometric data among the principal components.

\begin{tabular}{ccc}
\hline PC & EIGEN VALUES & \% VARIANCE \\
\hline 1 & 159.064 & 36.002 \\
2 & 55.2445 & 12.504 \\
3 & 48.6233 & 11.005 \\
4 & 43.8013 & 9.9137 \\
5 & 15.9893 & 3.6189 \\
6 & 14.7403 & 3.3362 \\
7 & 14.0538 & 3.1809 \\
8 & 13.522 & 3.0605 \\
9 & 11.295 & 2.5565 \\
10 & 9.48086 & 2.1458 \\
11 & 8.14853 & 1.8443 \\
12 & 7.4755 & 1.692 \\
13 & 6.0839 & 1.377 \\
14 & 5.7027 & 1.291 \\
15 & 5.207 & 1.179 \\
\hline
\end{tabular}


Table 2: : Distribution of variation of meristic data among the principal components

\begin{tabular}{lll}
\hline PC & Eigen value & \% variance \\
\hline 1 & 5.4676 & 50.316 \\
2 & 2.9759 & 27.386 \\
3 & 1.1695 & 10.763 \\
4 & 0.8393 & 7.724 \\
5 & 0.4142 & 3.811 \\
6 & 0 & 0 \\
\hline
\end{tabular}

\section{DISCUSSION}

In this study, measurements of morphometric characters as well as meristic counts were used to characterize fish populations as they still remain dependable tools especially on the field and they are sensitive to any environmental changes (Fryer and Iles, 1972). Significant morphological heterogeneity was evident among the three population samples of Tilapia rillii although the level of differentiation between them varies across the three populations.

The overlap of data between populations of $T$. zillii from Opa Reservoir (red), and Asejire reservoir (green) as observed on the CVA scatter diagram implies that these populations are similar morphologically. Likewise the slight overlap between T. zillii populations from Opa Reservoir (red) and Ero reservoir (Blue) implies that these populations are somewhat morphologically related.

However, the clear separation between the $T$. zillii populations from Ero and Asejire reservoirs as indicated on the CVA diagram implies that these populations are phenotypically separable based on their mophometric characters. This is consistent with the report of Khayyami et al. (2015) who used univariate analysis of variance and PCA to study morphological variability in two separate populations of Liza klunzingeri in Northeastern Persian Gulf. They reported a high degree of phenotypic distinction between the two populations with respect to their morphometric characters.

The observed pattern of phenotypic discreteness among the studied T. zillii stock in the three reservoirs suggests a direct relationship between the extent of morphological differentiation and geographic separation, indicating that geographic separation is a limiting factor to migration among stocks (Khayyami et al., 2015). Much of the observed variation between populations of Tilapia zillii in Opa, Ero and Asejire reservoirs may also be due to differences in environmental conditions such as availability of food, presence of predators, water velocity, substratum, salinity, and temperature in the three water bodies.

Suneetha (2007) reported that populations of fishes inhabiting various ecosystems maintain morphological heterogeneity. The morphological variation can be used to differentiate some of these populations. Langerhans et al. (2003) also reported that morphological variation increases with increasing geographic distance between populations and with variation in other environmental factors.

Sufficient degree of isolation may result in notable morphological and genetic differentiation among stocks within a species; this may be recognized as a basis for the management of distinct stock (Mian et al., 2014). Similarly, under conditions of partial or complete isolation of groups of fish within a species, slight differences in body proportions or meristic characters may be preserved in each group (Alhstrom, 1957).

The meristic characters were unable to deliniate the T. zillii populations studied as a high level of homogeneity was observed when the three populations were subjected to CVA analysis. This is consistent with the report of Carscadden and Leggett (1975); Ihssen et al. (1981); Murta (2000) and Oladimeji et al. (2015) that in population differentiation studies, the pattern of 
differentiation shown by meristics is usually poor compared to that shown by morphometrics. Also, in this study the number of dorsal fin rays, dorsal fin spine, anal fin rays and anal fin spine from the three locations were fairly constant. This indicates identity in parental stock and agrees with the findings of Holden and Reed (1972) and Reed et al. (1967) that fin rays of the tribe Tilapiini do not vary much.

It has been reported that morphological characteristics of fish are determined by an interaction between genetic and environmental factors (Tudela, 1999). However, phenotypic variability may not necessarily reflect population differentiation at the molecular level (Tudela, 1999). This is because phenotypic variation of morphological characters at the intra-specific level is not solely influenced by genes but is also subjected to environmental modifications. Thus the observed phenotypic variation in this study may not reflect any population differentiation at the molecular level.

\section{CONCLUSION}

The study revealed that $T$. zillii sampled from Ero and Asejire reservoirs were phenotypically separable populations of the same species while those from Opa reservoir are a little similar to both of them. The results established heterogeneity in morphology among populations of Tilapia zillii inhabiting the three different reservoirs of study based on univariate and multivariate analysis of the morphometric characters. However, molecular analysis is recommended in order to ascertain the population differentiation pattern of Tilapia zillii in the studied reservoirs.

\section{REFERENCES}

Adedeji, O. J. 1993.The Socio-Economic Characteristics of River-Dam Development on Non-Metropolitan Communities. A case Study of Ero Dam at Ikun Ekiti. BSc. Thesis, University of AdoEkiti, Ekiti State.67 pp.

Adesulu, E.A. and Sydenham, D.H.J. 2007. The Freshwater Fishes and Fisheries of Nigeria.Macmillian Nigerian Publishers Ltd. 379 pp.

Agbabiaka, L.A. 2010. The current Ichtyofauna of
River Otamiri, South-Eastern Nigeria. International Journal of Tropical Agriculture andFood Systems 4(1): 7-9.

Akinbuwa, O. and Adeniyi, I.F. 1996. Seasonal variation, distribution and interrelationships of rotifers in Opa Reservoir, Nigeria African Journal of Ecology 34:351-363.

Ahlstrom, E. H. 1957. A Review of Recent Studies of Sub-populations of Pacific Fishes. In:

Contribution to the Study of Sub-populations of Fishes. Special scientific Report - Fisheries No. 208 U.S. Dept of Interior.Fish and Wildlife Service.78-89 pp.

Allendorf, F.W., Ryman, N. and Utter, F.M. 1987. Genetics and Fishery Management.In Population Genetics and Fishery Management, University of Washington. pp. 1-9.

Ayodele, H. A. 1979. The influence of some physico-chemical factors on the composition, abundance and character of zooplankton in some Lakes in Osun River Basin. M. Sc. Thesis, University of Ife, IleIfe, Nigeria.

Bentzen P., McPhail, J.D. 1984. Ecology and eviolution of sympatric sticklebacks (Gasterosteus)- specialization for alternative trophic niches in the Enos lake species pair Canadian. Journal of ZoologyRevue Canadienne De Zoologie 62: 2280-2286

Cadrin, S.X. 2000. Advances in Morphometric Identification of Fishery Stocks. Reviews in Fish Biology and Fisheries 2: 91-112

Carscadden, J.E. and Leggett, W.C. 1975. Meristic differences in spawning populations of American shad, Alosasa pidissima: evidence forhoming to tributaries in the St John River, New Brunswick. Journal of the Fisheries Research Board of Canada 32:653660.

Cresko, W.A. and Baker, J.A. 1996 Two morphotypes of lacustrine three spine sticklehack, Gasterosteus aculeatus, in Benka Lake, Alaska.Environmental Biology of Fishes 45:343-350.

Deesri, U., Cavin, L., Claude, J., Suteethorn, V. and Yuangdetkla, P. 2009.Morphometric and Taxonomic Study of a Ray Finned Fish Assemblage (Lepidotesbud dhabutrensis, Semionotidae) from the Late Jurassicearliest Cretaceous of NE 
Thailand.Geological Society of London Special Publication 315: 115-124.

Doherty, D. and McCarthy, T.K. 2004.Morphometric and merisitic characteristics analysis of two western Irish populations of Arctic Char, Salvelinusalpilus (L.). Royal Irish. Academy104B: 75-85.

Dunz, A. and Schliewen, U.K. 2010. Description of a Tilapia (Coptodon) Species Flock of Lake Ejagham (Cameroon), (Perciformes, cichlidae).Spixiana 33(2): 251-280.

Eklov P. and Jonsson P. 2007. Pike predators induce morphological changes in young perch and roach. Journal of Fish Biology 70: 155-164.

Fryer, G. and Iles, T. D. (1972): The Cichlid Fish of the Great Lakes of Africa. Oliver and Boyd, Edinburgh. 641 pp.

Hammer, O., Harper, D.A.T. and Ryan, P. D. 2001. PAST: Paleontological Statistics Software Package for Education and Data Analysis.Paleontologia electronica 4(1):5056.

Hold M. and Reed W. 1972. West African fresh water fish, 1st ed. West African Nature Handbooks, Longmans.

Ihssen, P.E., Booke, H.E, Casselman, J.M., Glade, M.C., Payne N.R. and Utter, F.M. 1981. Stock identification: materials and methods. Canadian Journal of Fisheries and Aquatic Sciences 38:1838-1855.

Ipinmoroti, M. O. (2013). Ichthyofauna diversity of Lake Asejire: Ecological implications. International Journal of Fisheries and Aquaculture 5(10): 248- 252.

Jayasankar, P., Thomas, P.C., Paulton, M.P. and Mathew,J. 2004. Morphometric and Genetic Analysis of Indian Mackerel (Rastrelliger kanangurta) from Peninsular India. Asian Fishries Society 17:201-215.

Khayyami, H.,Zolgharnein, H., Salamat, N. and Movahedinia, A. 2015. Morphological Variability of Liza klunzingeri (Day, 1888) from Bandar Abbas Port and Qeshm Island in Northeastern Persian Gulf.Journal of Fisheries and Aquatic Science 10:191-198.

Kristjánsson, B. K. 2002. Morphological segregation of Icelandic threespine stickleback (Gasterosteus aculeatus L).
Biological Journal of the Linnean Society 76(2): 247-257.

Langerhans, B.R., Layman, C.A., Langerhans, A.K. and Dewitt, T.J. 2003. Habitatassociated morphological divergence in two Neotropical fish species. Biol. J. Linn Soc. 80:689-698.

Lim, C.E. and Webster, C.D. 2006. Tilapia: Biology, Culture and Nutrition. Food Products Press, New York, USA, pp.469501.

Mian, J., Hussain, S.M. Siddiqui, P.J.A. and Immink, A. 2014. Haematological, biochemical and cephalus L. on shrimp head protein hydrolysate and macroalgae based diets. World J. Fish Mar. Sci. 6: 295304.

Murta, A.G. 2000. Morphological variation of horse mackerel (Trachurus trachurus) in the Iberian and North African Atlantic: implications for stock identification. ICES Journal of Marine Science 57(4):1240-1248.

Oladimeji, T. E., Awodiran, M.O. and Komolafe O.O. 2015. Genetic Differentiation Studies among Natural Populations of Tilapia rillii. Notulae Scientia Biologica 7(4):423-429.

Omoniyi I.T. and Agbon A.O. 2008. Morphometric Variations in Sarotherodon melanotheron

(Pisces: Cichlidae) from Brackish and Fresh Water Habitats in South-western Nigeria. West African Journal of Applied Ecology 12.

Paugy, D., Leveque, C. and Teugels, G.G. 2003. The fresh and brackish water fishes of West Africa Volume I and II. IRD Editions.Publications scientifiques.Du museum. 457 and $815 \mathrm{pp}$.

Pinheiro, A., Teixeira, C.M., Rego, A.L., Marques, J.F. and Cabral, H.N. 2005. Genetic and morphological variation of Soleal ascaris (Risso, 1810) along the Portuguese coast. Fisheries Research 73(1-2): 67-78.

Reed, W., Burchard, J., Hopson, A. J., Jenness, J. and Yaro, I. 1967.Fish and fisheries of northern Nigeria.Gaskiyya Corporation, Zaria.

Reist, J. D. 1985. An Empirical Evaluation of Several Univariate Methods that Adjust for Size Variation in Morphometric Data.Canadian Journal of Zoology 63: 1429- 
1439

Robinson, B.W. and Wilson, D.S. 1994. Character release and displacement in fishes: a neglected literature. Am Nat, 144: 596627.

Schluter, D. 1995.Adaptive radiation in sticklebacks-trade-offs in feeding performance and growth. Ecology 76: 82-90.

Solomon, S. G. Okomoda, V.T. Ogbenyikwu A. I. 2015. Intraspecific morphological variation between cultured and wild Clarias gariepinus (Burchell) (Clariidae, Siluriformes) Arch. Pol. Fish. 23: 53-61.

Suneetha, G.K.B. (2007): Morphological heterogeneity and population differentiation in the green chromide Etroplus suratensis (Pisces: Cichlidae) in Sri Lanka. Ceylon. Journal of Biological Sciences 36(2): 100-107.

Svanback, R. and Eklov, P. 2006. Morphology dependent foraging efficiency in perch: a trade-off for ecological specialization? Oikos 102: 273-284.

Swain, D. P., Riddell B. E. and Murray, C. B. 1991. Morphological differences between hatchery and wild populations of coho salmon (Oncorbynchus kisutch): Environmental versus genetic origin. Can. J. Fish. Aquat. Sci. 48: 1783-1791.

Tudela, S. 1999. Morphological variability in a Mediterranean, genetically homogeneous population of the European anchovy, Engraulisen crasicolus.Fish. Res. 42: 229-243.

Ukenye E. A., Taiwo I. A., Ezekiel M. O., Udoezika, U. C. 2015. Morphological Variation of Ten Tilapia guineensis Populations in Selected Rivers in Nigerian coastal waters. International Journal of Sciences: Basic and Applied Research (IJSBAR) 24 (1):273-284.

Webster, M.M., Atton, N., Hart, P.J.B. and Ward, A.J.W. 2011. Habitat-Specific Morphological Variation among Threespine Sticklebacks (Gasterosteus aculeatus) within a Drainage Basin. PLOS ONE 6 (6): e 21060 . doi:10.1371/journal.pone.0021060.

Wimberger, P. H. 1992. Plasticity of Food Body Shape- The Effects of Diet, Development, Family and Age in Two Species of Geophagus (Pisces: Cichlidae). Biological Journal Society 45: 197-218. 